\title{
The Effect of Commercial Rice Husk Ash Additives on the Porosity, Mechanical Properties, and Microstructure of Alumina Ceramics
}

\author{
Mohammed Sabah Ali, ${ }^{1,2}$ M. A. Azmah Hanim,, ${ }^{1,3}$ S. M. Tahir, ${ }^{1}$ C. N. A. Jaafar, ${ }^{1}$ \\ Norkhairunnisa Mazlan, ${ }^{3,4}$ and Khamirul Amin Matori ${ }^{5}$ \\ ${ }^{1}$ Department of Mechanical and Manufacturing Engineering, Faculty of Engineering, \\ Universiti Putra Malaysia, 43400 Serdang, Selangor, Malaysia \\ ${ }^{2}$ Department of Agriculture Machinery \& Equipment Engineering Techniques, Technical College, Al-Mussaib, Iraq \\ ${ }^{3}$ Laboratory of Biocomposite Technology, Institute of Tropical Forestry and Forest Products, \\ Universiti Putra Malaysia, 43400 Serdang, Selangor, Malaysia \\ ${ }^{4}$ Department of Aerospace Engineering, Faculty of Engineering, Universiti Putra Malaysia, 43400 Serdang, Selangor, Malaysia \\ ${ }^{5}$ Department of Physics, Faculty of Science, Universiti Putra Malaysia, 43400 Serdang, Selangor, Malaysia
}

Correspondence should be addressed to Mohammed Sabah Ali; mohammed.sabah94@yahoo.com

Received 27 September 2016; Revised 21 November 2016; Accepted 30 November 2016; Published 4 January 2017

Academic Editor: Amit Bandyopadhyay

Copyright (C) 2017 Mohammed Sabah Ali et al. This is an open access article distributed under the Creative Commons Attribution License, which permits unrestricted use, distribution, and reproduction in any medium, provided the original work is properly cited.

\begin{abstract}
A porous ceramic is made from composite materials which consist of alumina and commercial rice husk ash. This type of ceramics is obtained by mixing the commercial rice husk ash as a source of silica $\left(\mathrm{SiO}_{2}\right)$ and a pore forming agent with alumina $\left(\mathrm{Al}_{2} \mathrm{O}_{3}\right)$ powder. To obtain this type of ceramic, a solid-state technique is used with sintering at high temperature. This study also investigated the effects of the rice husk ash ratios on the mechanical properties, porosity, and microstructure. The results showed that, by increasing the content of the rice husk ash from 10 to $50 \mathrm{wt} \%$, there is an increase in the porosity from $42.92 \%$ to $49.04 \%$, while the mechanical properties decreased initially followed by an increase at $30 \mathrm{wt} \%$ and $50 \mathrm{wt} \%$; the hardness at $20 \mathrm{wt} \%$ of the ash content was recorded at $101.90 \mathrm{HV}_{1}$. When the ash content was increased to $30 \mathrm{wt} \%$ and $50 \mathrm{wt} \%$, the hardness was raised to $150.92 \mathrm{HV}_{1}$ and $158.93 \mathrm{HV}_{1}$, respectively. The findings also revealed that the tensile and compressive strengths experienced a decrease at $10 \mathrm{wt} \%$ of the ash content and after that increase at $30 \mathrm{wt} \%$ and $50 \mathrm{wt} \%$ of rice husk ash. XRD analysis found multiple phases of ceramic formation after sintering for the different rice husk ash content.
\end{abstract}

\section{Introduction}

Porous ceramic material is commonly used in the filtration of liquids and gases, absorption of shock, catalyst support, molten-metal filtration, thermal insulators, high temperature applications, and environmental protection [1-4]. This is due to its excellent properties, which include resistance to high temperature and chemical corrosion and low thermal conductivity as well as high surface area and low density [13]. The mullite ceramic phase is important in the $\mathrm{Al}_{2} \mathrm{O}_{3}-\mathrm{SiO}_{2}$ system. The mullite phase has good mechanical and physical properties [5] such as high oxidation resistance, excellent chemical stability, good creep resistance, and low thermal conductivity $[1,6,7]$. In addition, porous mullite ceramic has many important uses, for example, in insulating materials, catalyst support insulation, and membrane filters for gases [8].

One of the most common and effective ways for the manufacturing of porous ceramic is the pore-forming method $[4,9]$. Recently, there has been renewed interest in using agricultural waste materials in porous ceramics. Sengphet et al. [10] used wastes from kenaf powder for the fabrication of porous clay ceramics, while Njeumen Nkayem et al. [11] used corn cob for the preparation of porous ceramic brick. As for 
Sooksaen et al. [12], they used wood dust as a pore agent in producing porous glass ceramics. Unfortunately, most of the pore agents that have been used to produce porous ceramics have resulted in a decrease in the mechanical properties due to porosity. This paper recommends the use of commercial rice husk ash from agricultural waste as a source of silica $\left(\mathrm{SiO}_{2}\right)$ and as a pore forming agent for producing porous mullite and cristobalite-corundum ceramics. Commercial rice husk ash is directly mixed with different ratios in the alumina matrix using commercial sucrose (sugar) as a binder and sintered at high temperature to produce porous mullite and cristobalite-corundum ceramics. Previously, several researchers used the $\mathrm{Al}_{2} \mathrm{O}_{3}-\mathrm{SiO}_{2}$ system to produce porous ceramics with good mechanical properties. Dong et al. [13] used a mixture of fly ash from industrial waste and bauxite to fabricate bulk porous mullite supports for ceramic membranes using dry pressing and sintering. Serra et al. [8] used rice husk ash to produce mullite ceramics through a sintering reaction of alumina and rice husk ash using different sintering temperatures. Cao et al. [14] prepared lowcost porous mullite supports for ceramic membranes using recycled coal fly ash with natural bauxite. While Hua et al. [1] fabricated anorthite-mullite-corundum porous ceramics using the waste from construction sites and alumina powder $\left(\mathrm{Al}_{2} \mathrm{O}_{3}\right)$. Therefore, the aim of this study is to produce mullite and cristobalite-corundum ceramic composite materials with high porosity and mechanical properties but low cost through the direct mixing of commercial rice husk ash and alumina powder, followed by sintering at high temperature.

\section{Experimental Procedure}

2.1. Materials and Specimen Preparation. The matrix materials used included a commercial aluminum oxide $\mathrm{Al}_{2} \mathrm{O}_{3}$ pow$\operatorname{der}\left(\rho=3.94 \mathrm{~g} / \mathrm{cm}^{3}\right)$ with high level of purity $(99.99 \%)$ and a particle size of $0.5 \mu \mathrm{m}$. Commercial sucrose (sugar) used as the binder (10\%) was added to the ceramic mixture according to the maximum solubility of sugar in distilled water. For the use of the binder in this study, the concentration was fixed at $60 \mathrm{wt} \%$ [15]. The binder was mixed manually with ceramic powder for 3-5 minutes using an agate mortar. Then, the rice husk ash powder was added to the ceramic slurry at ratios of 10, 20, 30, 40, and $50 \mathrm{wt} \%$. After that, all the batches were mixed in a mortar for around 5-10 minutes followed by ball milling for $3 \mathrm{hrs}$ in a plastic container homogenously mixed at a ratio of weight $3: 1$, which is 3 parts alumina balls to one part weight of powder. Later, the dry mixtures were pressed uniaxially in a circular steel die (diameter $=20 \mathrm{~mm}$ and thickness $=5 \mathrm{~mm}$ ) using an Instron hydraulic press at a pressure of $90 \mathrm{MPa}$. Following this, the green compacts were dried in the oven at $110^{\circ} \mathrm{C}$ for $24 \mathrm{hrs}$. The organic burnout of the dried samples was carried out in an ambient atmosphere in an electrically heated, programmable furnace. The rate of heating was set at $1.5^{\circ} \mathrm{C} / \mathrm{min}$ for each increment in the temperature. According to the TGA (thermogravimetric analysis) of sucrose and rice husk ash, the samples were sintered at $200^{\circ} \mathrm{C}, 300^{\circ} \mathrm{C}, 500^{\circ} \mathrm{C}$, and $900^{\circ} \mathrm{C}$ in an electric furnace for a duration of $1 \mathrm{hr}$ of soaking time. The rate of heating and cooling was fixed at $1.5^{\circ} \mathrm{C}$ for the removal of the carbon and organic materials in the rice husk ash as well as the sucrose. After that, the ceramic specimens were sintered at $1600^{\circ} \mathrm{C}$ for a duration of $2 \mathrm{hrs}$ of soaking time while the rate of heating and cooling was fixed at $5^{\circ} \mathrm{C} / \mathrm{min}$. The findings revealed that all the samples with different ratios of rice husk ash and (binder) sucrose showed uniform dimensions without cracks after undergoing sintering.

2.2. Ceramic Samples Characterisation. The microstructure and the chemical composition of the porous ceramics were examined using a field emission scanning electron microscope (FESEM) and an EDX technique (SE-440). The phase compositions of the porous ceramics were determined using an X-ray diffractometer (PANAlytical (Philips) X'pert ProPW3050/60) with $\mathrm{Cu}$ radiation (wave length = $1.54060 \AA$ ) that had been set at $40 \mathrm{~mA}$ and $40 \mathrm{Kv}$ using X-pert software.

The pore size distribution was determined from the FESEM images that had been taken using the image analysis software (image-J) [16, 17]. The compressive strength of the samples with dimensions of $20 \mathrm{~mm}$ in diameter and $24 \mathrm{~mm}$ in height were measured using an Instron machine. The measurements were in accordance with the ASTM-142410 standard [18] at a crosshead rate of $0.5 \mathrm{~mm} / \mathrm{min}$. The maximum mechanical load and cross-sectional area were used to calculate the compressive strength of the samples [19]. The hardness values of the samples were measured. A micro Vickers hardness machine was used to measure the value of the hardness of the samples whereby the applied force was $9.81 \mathrm{~N}$ for $15 \mathrm{sec}$ at full load [20]. All the samples were ground and polished using polishing media and then thermally etched. A Brazilian test was performed using samples of dimensions $20 \mathrm{~mm}$ in diameter and $5 \mathrm{~mm}$ in thickness by means of an Instron machine. An average of five samples was used to obtain the average value for the strength and hardness for each composition. The calculation of the diametrical tensile strengths of the porous alumina ceramics was based on the tensile strength of the Brazilian test.

$$
\sigma(\text { tensile } \mathrm{MPa})=\frac{(2 * P)}{(\pi * t * d)},
$$

where $\sigma$ (compressive) is in $\mathrm{MPa}, P$ is the applied force $(\mathrm{N})$, $d$ is the diameter of the samples ( $\mathrm{mm})$, and $t$ is the thickness of the sample (mm) [21].

A water immersion method based on Archimedes' principle, as specified in ASTM C20-00, was used to determine the overall porosity, density, and open porosity of the sintered samples using the following equations:

$$
\begin{gathered}
P_{\text {open }}=\frac{M_{\text {wet }}-M_{\text {dry }}}{M_{\text {wet }}-M_{\text {suspended }}+M_{\text {wire }}} \\
P_{\text {overall }}=\left(1-\frac{\rho}{\rho_{\text {theoritical }}}\right) \times 100 \\
\rho=\frac{M_{\text {dry }} \times \rho_{\text {water }}}{M_{\text {wet }}-M_{\text {suspended }}+M_{\text {wire }}}
\end{gathered}
$$


TABLE 1: The chemical compositions of rice husk ash powder and sucrose.

\begin{tabular}{|c|c|c|c|c|c|c|c|c|c|c|}
\hline Materials & Elements & $\mathrm{C}$ & $\mathrm{O}_{2}$ & $\mathrm{Si}$ & $\mathrm{P}$ & $S$ & $\mathrm{~K}$ & $\mathrm{AL}$ & $\mathrm{Mg}$ & $\mathrm{Ca}$ \\
\hline Rice husk ash & Weight $\%$ & 6.78 & 56.40 & 35.74 & - & - & - & - & 0.43 & 0.66 \\
\hline Sucrose (sugar) & Weight $\%$ & 59.13 & 40.88 & - & & - & & - & - & - \\
\hline
\end{tabular}

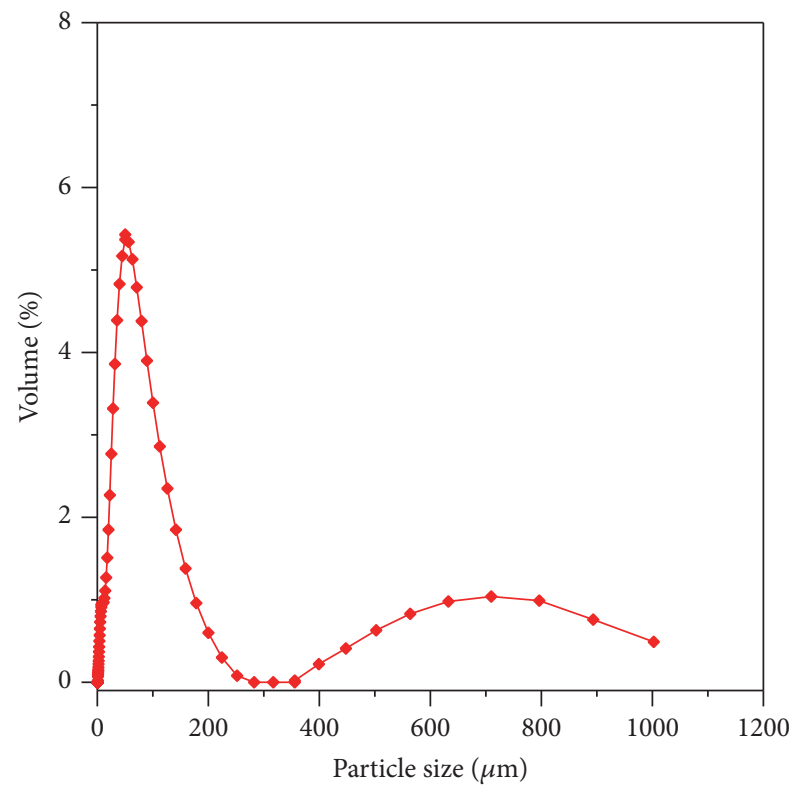

FIGURE 1: Distribution of particle size of the rice husk ash powder.

where $M_{\text {dry }}$ is the dry mass [22] of the sample, $M_{\text {suspended }}$ is the mass of the sample suspended in distilled water, $M_{\text {wet }}$ is the mass of the sample after soaking in water, $M_{\text {wire }}$ is the mass of the suspending system, $P_{\text {overall }}$ is the volume fraction of the overall porosity (vol.\%) of the sample, and $P_{\text {open }}$ is the volume fraction of the open porosity of the sample $[23,24]$. The theoretical density (true) of alumina $\left(\mathrm{Al}_{2} \mathrm{O}_{3}\right)$, recorded at $3.94 \mathrm{~g} / \mathrm{cm}^{3}$, has been used as a reference. This measurement was obtained using the Accupyc II 1340. The relative density of the porous alumina ceramic samples was determined from the ratio of the measured bulk density to the theoretical density [25].

\section{Results and Discussion}

3.1. Characterisation of the Rice Husk Ash and Binder. The commercial rice husk ash was ground in an electrical grinder (type RT-02A, $3000 \mathrm{rpm}$ ) for $1 \mathrm{~min}$. Then, it was sieved in an electrical sieve (type Retsch, As 200) to obtain a particle size of $250 \mu \mathrm{m}$.

The actual measurement of the density of rice husk ash powder was obtained using a gas pycnometer (Accupyc II 1340). Meanwhile, a particle size analyser (Malvern, master size 2000) was used to analyse the distribution of particle size for the rice husk ash powder as shown in Figure 1.

The actual measurement of the density for rice husk ash is $2.17 \mathrm{~g} / \mathrm{cm}^{3}$ as indicated by the Accupyc II 1340. The thermogravimetric (TGA) tests for rice husk ash and sucrose (sugar) powder were conducted under nitrogen gas at a temperature rate of $10^{\circ} \mathrm{C} / \mathrm{min}$. It is necessary to perform TGA analysis of the rice husk ash in order to determine the thermal decomposition range.

Figures 2(b) and 2(c) are the FESEM images of the rice husk ash delivered from the factory and the sucrose. The average length of the rice husk ash particles was $355.3 \mu \mathrm{m}$. The FESEM image of the sucrose shows the shape of the sucrose particles.

Figure 2(a) presents the TGA results of commercial rice husk ash and sucrose. The weight loss of the rice husk ash is around $6.48 \%$. The removal of the unburnt elements and organic materials, such as carbon, started from around $200^{\circ} \mathrm{C}$ to $650^{\circ} \mathrm{C}$. The maximum weight loss occurs at approximately $300^{\circ} \mathrm{C}$.

Based on the weight loss of the rice husk ash, the pyrolysis of the rice husk ash was incomplete. This incomplete pyrolysis of the rice husk ash was attributed to the presence of ceramic oxide $\left(\mathrm{SiO}_{2}\right)$. Meanwhile, the decomposition and burning of the organic materials in the sucrose take place between $180^{\circ} \mathrm{C}$ and $500^{\circ} \mathrm{C}$ based on the sucrose TGA. Based on the TGA data of rice husk ash and sucrose, the sintering temperature of porous alumina ceramics was selected in order to perform the sintering process $[26,27]$. It is necessary to achieve a controlled burnout process for the rice husk ash and sucrose in order to obtain defect free samples [28].

The chemical compositions of rice husk ash and sucrose (sugar) were measured using an EDX machine. Table 1 shows the chemical compositions of the powder obtained from rice husk ash and sucrose.

Figure 3 shows the results obtained from the XRD and EDX tests for rice husk ash. The findings reveal the presence of amorphous silica $\left(\mathrm{SiO}_{2}\right)$ in the powder of the rice husk ash. This agrees with the chemical compositions tabulated in Table 1 .

3.2. The Porosity, Density, Mechanical Properties, and Pore Size Distribution of Porous Ceramics. Generally, rice husk plays a role in the formation of pores due to the nature of its composition. Rice husk consists of ash (17-23\%), fixed carbon (10-15\%), and volatile matter (60-65\%). Rice husk comprises around $20 \%$ silica, $30 \%$ group of lignin, and $40 \%$ cellulose [29]. Therefore, after burning the materials inside the ceramic during sintering, materials such as carbon, cellulose, and a group of lignin will turn into another form such as $\mathrm{CO}_{2}$ and evaporate, which leads to the formation of pores in the ceramic body, and around $92-97 \%$ silica with other oxides in a minor percentage will remain in the matrix. The silica $\left(\mathrm{SiO}_{2}\right)$ in the rice husk or rice husk ash is found in either an amorphous or crystalline form [30]. In addition, the rice husk has an important effect on the sinterability of the ceramic body. As compared to other 


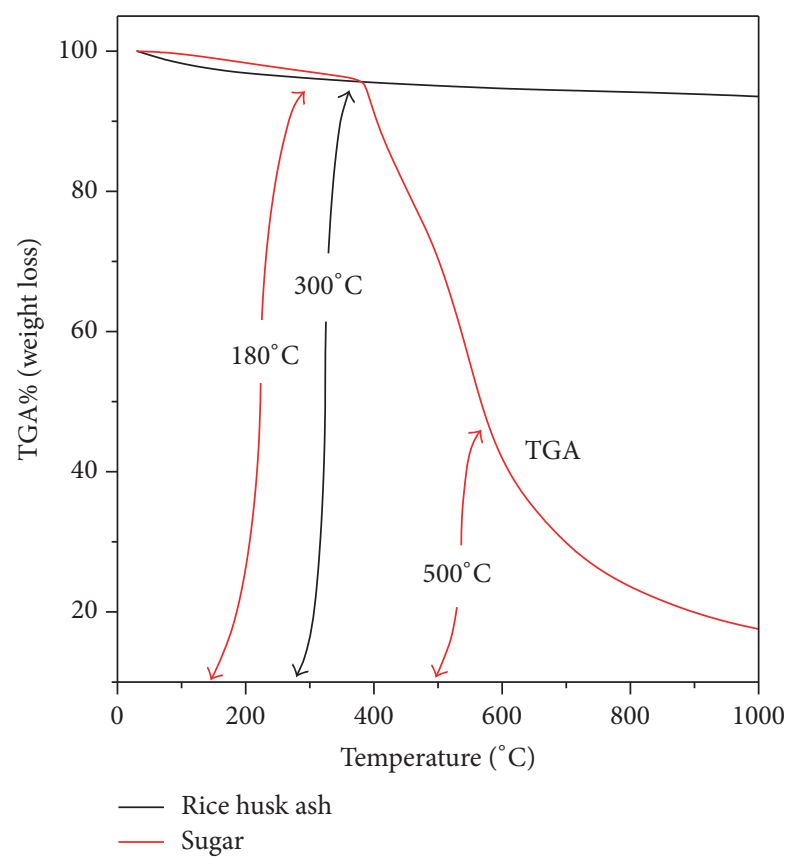

(a)

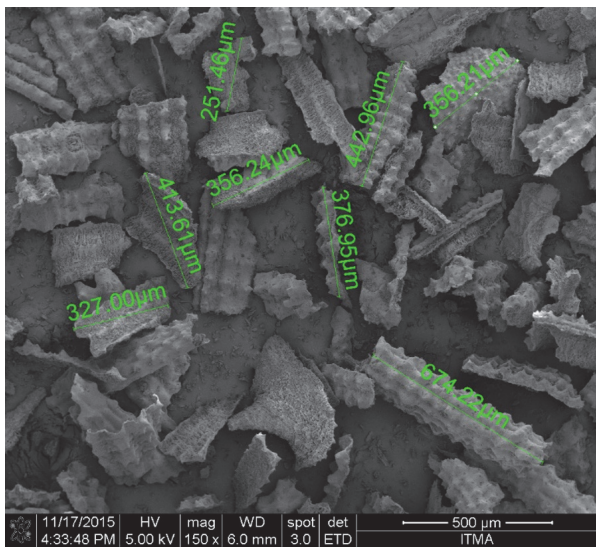

(b) Rice husk ash

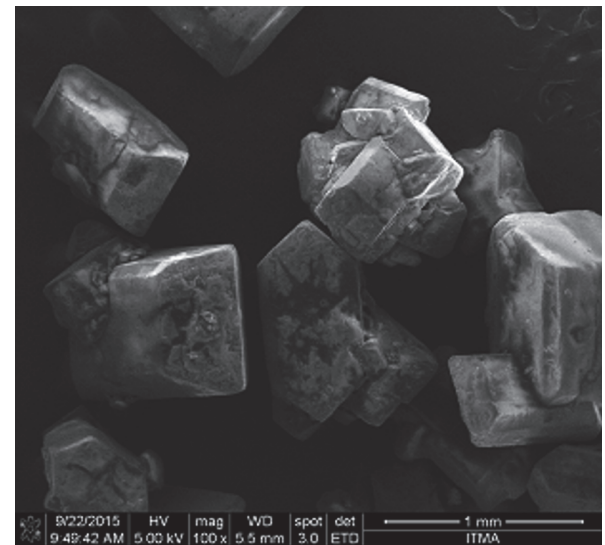

(c) Sugar

FIGURE 2: (a) TGA, (b) FESEM images of the rice husk ash, and (c) sucrose.

TABLE 2: Different ratios of rice husk ash with alumina used to fabricate porous ceramics, porosity characterization, and density.

\begin{tabular}{|c|c|c|c|c|c|c|}
\hline $\begin{array}{l}\text { Rice husk ash content } \\
(\mathrm{wt} \%)\end{array}$ & $\begin{array}{c}\mathrm{Al}_{2} \mathrm{O}_{3} \text { ratio } \\
(\mathrm{wt} \%)\end{array}$ & $\begin{array}{l}\text { Overall porosity } \\
(\text { vol } \%)\end{array}$ & $\begin{array}{l}\text { Open porosity } \\
\text { (vol\%) }\end{array}$ & $\begin{array}{l}\text { Green density } \\
\left(\mathrm{g} / \mathrm{cm}^{3}\right)\end{array}$ & $\begin{array}{l}\text { Sintered bulk density } \\
\left(\mathrm{g} / \mathrm{cm}^{3}\right)\end{array}$ & $\begin{array}{c}\text { Relative density } \\
(\%)\end{array}$ \\
\hline 0 & 100 & 18.45 & 10.76 & 1.92 & 2.99 & 75.89 \\
\hline 10 & 90 & 42.97 & 24.29 & 1.86 & 2.25 & 57.11 \\
\hline 20 & 80 & 48.09 & 27.38 & 1.76 & 2.04 & 51.78 \\
\hline 30 & 70 & 47.63 & 23.94 & 1.67 & 2.06 & 52.28 \\
\hline 40 & 60 & 49.44 & 24.00 & 1.58 & 1.99 & 50.51 \\
\hline 50 & 50 & 49.04 & 20.15 & 1.53 & 2.01 & 51.02 \\
\hline
\end{tabular}

factors, such as the sintering temperature which was constant $\left(1600^{\circ} \mathrm{C}\right)$ in this research study, the ratio of rice husk ash has more effect on the sintering parameters such as the density, average pore size, porosity, and the formation of the phases [8].
Table 2 shows the ratios for the rice husk ash, the bulk density for the green and sintered samples, the overall porosity, and the open porosity.

The bulk density and porosity were characterised quantitatively by determining the values of the overall and open 
TABLE 3: Mechanical properties of porous ceramics.

\begin{tabular}{lcccc}
\hline $\begin{array}{l}\text { Rice husk ash content } \\
(\mathrm{wt} \%)\end{array}$ & $\begin{array}{c}\text { Porosity } \\
(\mathrm{vol} \%)\end{array}$ & $\begin{array}{c}\text { Hardness } \\
\left(\mathrm{HV}_{1}\right)\end{array}$ & $\begin{array}{c}\text { Compressive strength } \\
(\mathrm{MPa})\end{array}$ & $\begin{array}{c}\text { Tensile strength } \\
(\mathrm{MPa})\end{array}$ \\
\hline 0 & 18.45 & $372.83 \pm 7.50$ & $218.66 \pm 2.52$ & $27.39 \pm 0.92$ \\
10 & 42.97 & $110.00 \pm 2.11$ & $59.81 \pm 2.27$ & $20.17 \pm 1.19$ \\
20 & 48.09 & $101.90 \pm 2.99$ & $59.33 \pm 3.96$ & $18.99 \pm 1.26$ \\
30 & 47.64 & $150.92 \pm 1.88$ & $69.72 \pm 2.87$ & $24.12 \pm 0.93$ \\
40 & 49.45 & $114.92 \pm 3.97$ & $53.87 \pm 1.55$ & $21.88 \pm 1.03$ \\
50 & 49.04 & $158.93 \pm 3.96$ & $60.14 \pm 2.01$ & $21.98 \pm 0.84$ \\
\hline
\end{tabular}
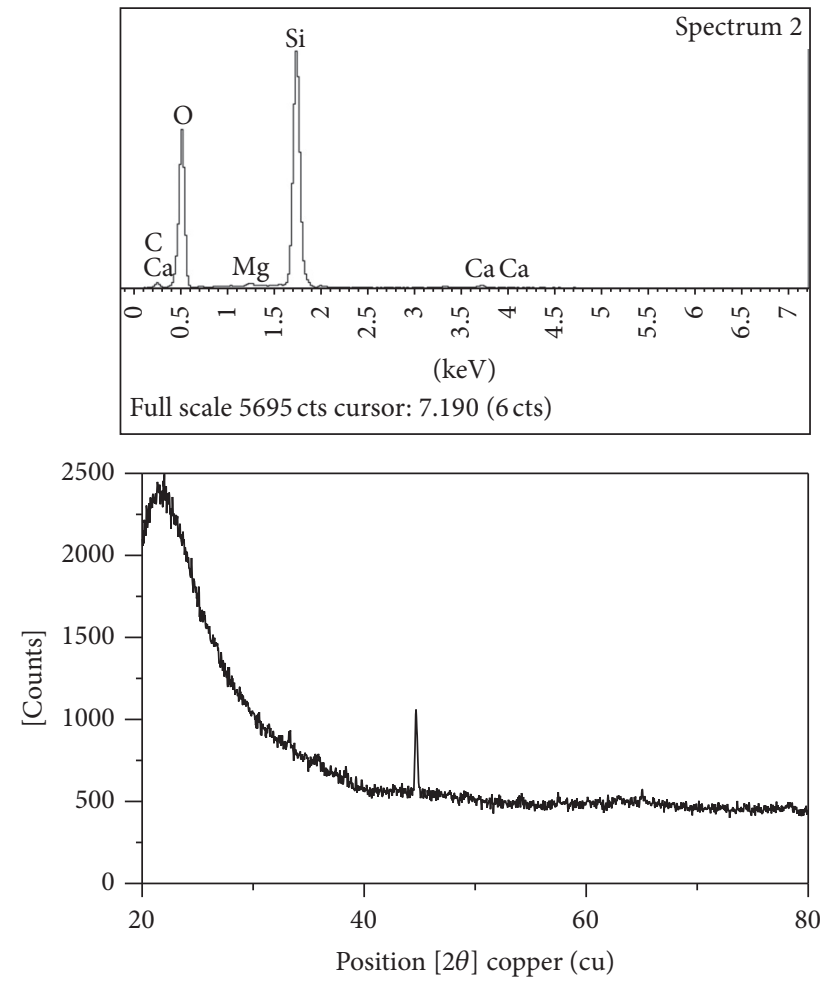

FIGURE 3: EDX and XRD for rice husk ash.

porosities of the samples of porous alumina. Figure 4 shows the variations of open and total porosities with different ratios of rice husk ash. An increase in the contents of rice husk ash showed an increase in the total and open porosities, followed by a decrease due to the formation of glassy phases [31]. Meanwhile, the green and bulk densities decreased from 1.92 to $1.53 \mathrm{~g} / \mathrm{cm}^{3}$ and from 2.99 to $2.01 \mathrm{~g} / \mathrm{cm}^{3}$, respectively. This is attributed to the burnout of the carbon, the organic materials, and the binder after sintering at high temperature [32]. The decrease in the green densities was attributed to the low density of rice husk ash $\left(2.17 \mathrm{~g} / \mathrm{cm}^{2}\right)$ compared with the density of the alumina matrix. The maximum porosity is at $49.45 \%$ while the lowest porosity is recorded at $42.97 \%$. Generally, the characteristics of the pores were categorised into pore size, pore morphology, and porosity. The pore morphology can be classified into closed and open pores. Closed pores are important for heat insulating materials and high weight materials, whilst open pores are beneficial for separation and filtration [27].

Table 3 shows the variations in the mechanical properties for the different ratios of rice husk ash content and porosity. Generally, the mechanical properties of the porous materials decrease with an increase in the porosity [33]. According to Rice's formula $\left(\sigma=\sigma \circ e^{(-b p)}\right)$, where $\sigma \circ$ and $\sigma$ are the strengths of the nonporous and porous materials, $b$ is the constant value related to the pore characteristics and $p$ is the porosity of the porous materials [34-36].

Figure 5 presents the data in Table 3 in graph form. Initially, the hardness of the porous alumina ceramics decreases at $20 \%$ after which it increases at $30 \%$ and $50 \%$, due to the variations of porosity and the formation of the ceramic phases, namely, mullite and cristobalite, which have a high value of hardness as shown in Figure 5(a) [37-39]. The compressive and tensile strengths of porous alumina ceramics reached a peak at $30 \%$ rice husk ash. This improvement in the mechanical properties was attributed to the formation of the phases of the ceramic, that is, mullite, cristobalite, and corundum. Figure 5(b) shows the variation of the porosities.

Figure 6 shows the distribution of the pore size (open pore) of the samples. The distribution of the pore size (open pore) was strongly affected by the ratios of rice husk ash. All the samples displayed a unimodal pore size distribution for all the ratios. The average pore sizes recorded were $18.28 \mu \mathrm{m}$ for $10 \mathrm{wt} \%$ rice husk ash, $28.35 \mu \mathrm{m}$ for $30 \mathrm{wt} \%$ rice husk ash, and $50.02 \mu \mathrm{m}$ for $50 \mathrm{wt} \%$ rice husk ash. It can be concluded that the shape and pore size distribution in porous ceramics corresponds to the required functions of certain applications [27]. Generally, during sintering at high sintering temperature with different ratios of rice husk ash, the relative density of the porous alumina ceramics has various values. With sintering at $1600^{\circ} \mathrm{C}$, the decrease in the relative density was in the range from $18.78 \%$ (relative density $57.11 \%$ ) to $24.84 \%$ (relative density $51.02 \%$ ) at $10 \mathrm{wt} \%$ and $50 \mathrm{wt} \%$ rice husk ash due to the porosity, which affected the pore size distribution. With a decrease in the relative density, the porosity increased, leading to pore formation. In addition, it can be seen that there is not much difference in the open pore size distribution above $20 \mathrm{wt} \%$ rice husk ash due to the presence of the glassy phase, which leads to an increase in the relative density of $52.28 \%$ at $30 \mathrm{wt} \%$ of rice husk ash and a decrease in the porosity to $47.63 \%$, resulting in little difference in the pore size of the ceramic body $[40,41]$. 


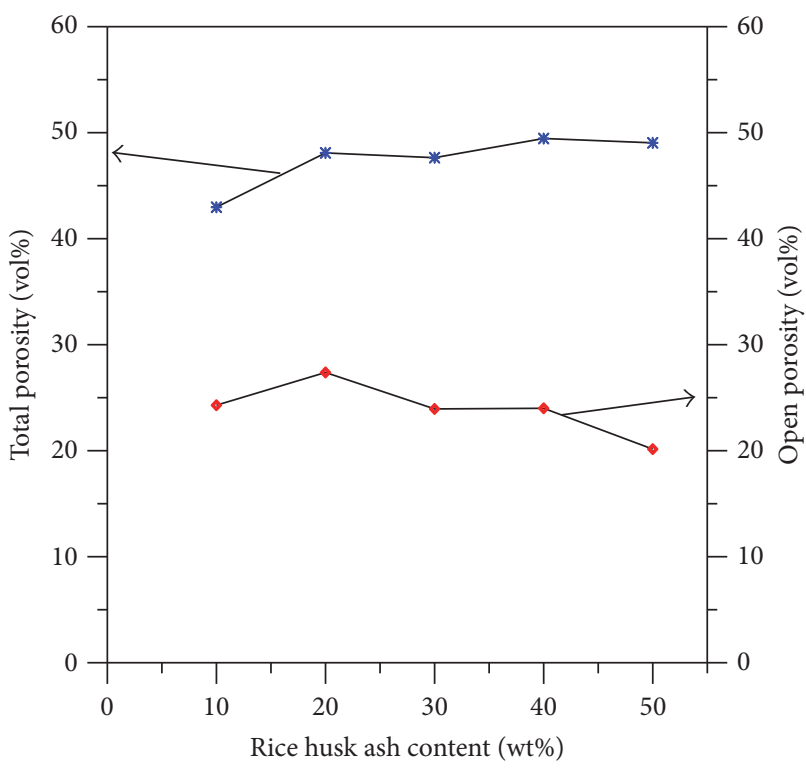

(a)

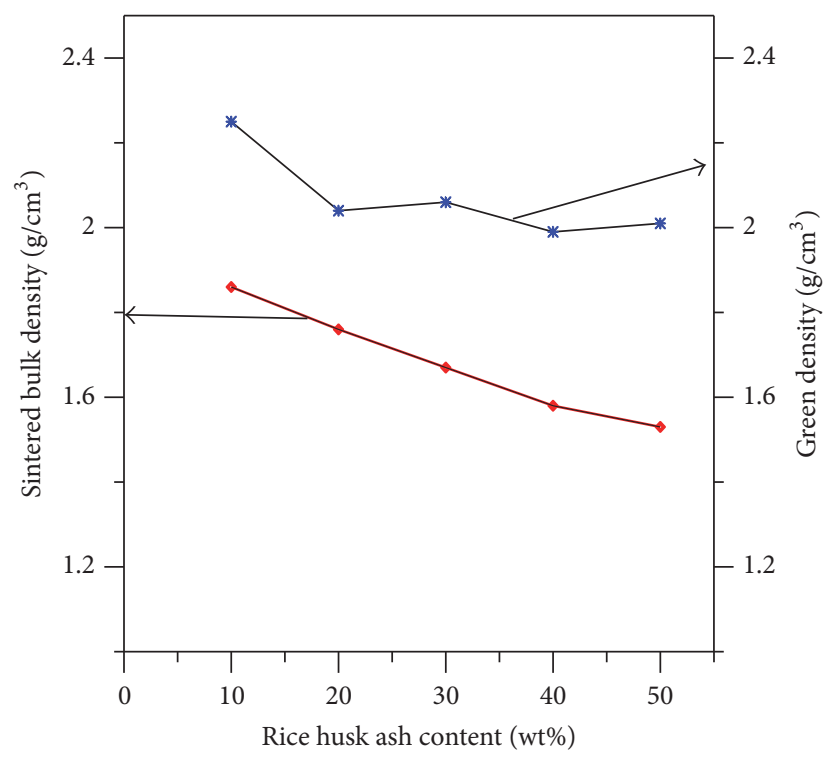

(b)

Figure 4: (a) Trend of total porosity and open porosity with increases in the content of rice husk ash; (b) trend of sintered bulk density and green density with increases in the content of rice husk ash. All samples were sintered at $1600^{\circ} \mathrm{C}$ for $2 \mathrm{hrs}$.

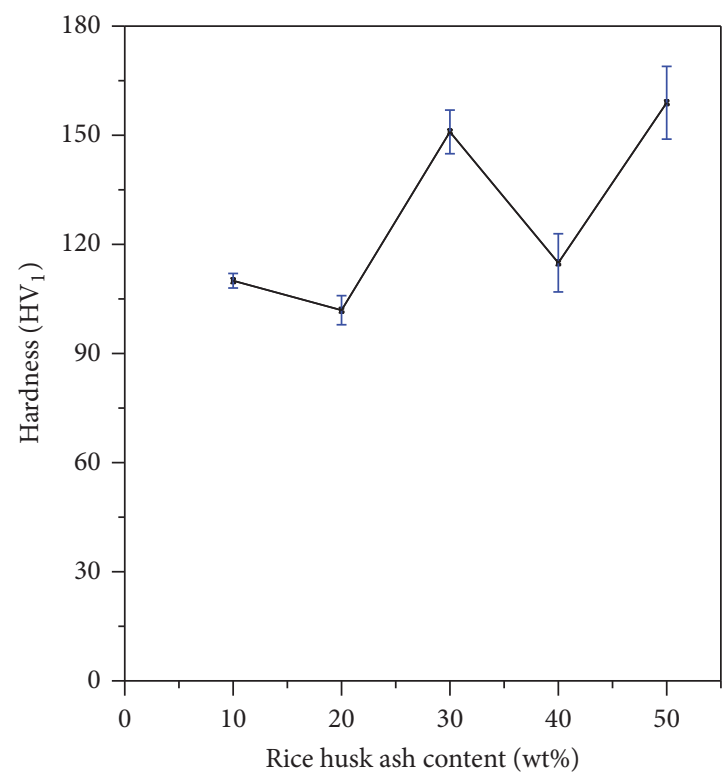

(a)

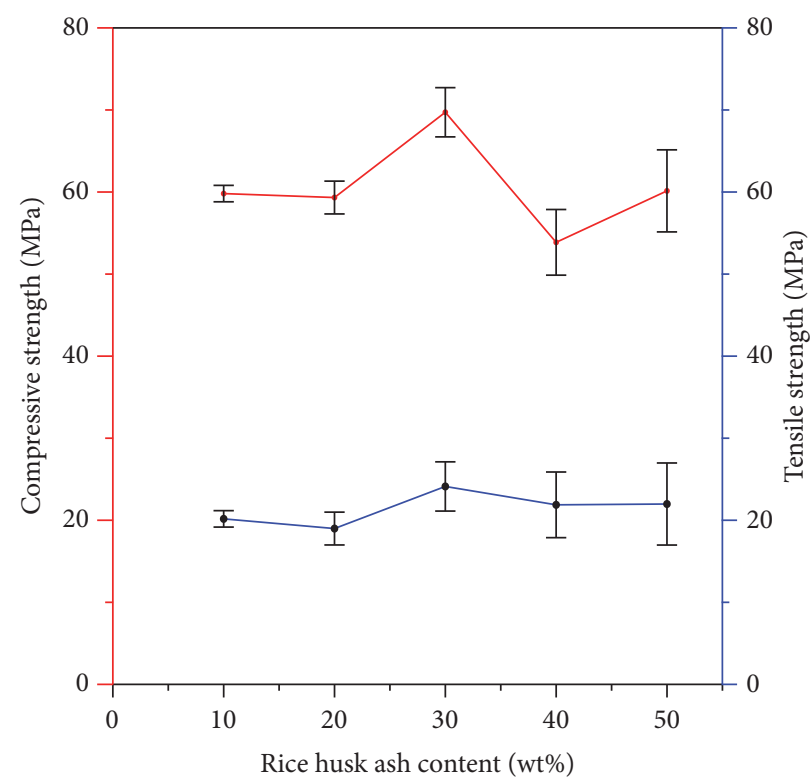

(b)

FIGURE 5: The variations in the mechanical properties of the content of rice husk ash of the samples of porous alumina ceramic sintered at $1600^{\circ} \mathrm{C}$ for $2 \mathrm{hrs}$; (a) hardness and (b) compressive strength and tensile strength.

3.3. XRD Analysis, $\mathrm{Al}_{2} \mathrm{O}_{3}-\mathrm{SiO}_{2}$ Reaction, and the Microstructure of Porous Alumina Ceramics. The objective of the XRD analysis in this research study is to observe the phase formation in the porous alumina ceramics and how it affects the mechanical properties. Figure 7 indicates that the XRD patterns of porous alumina ceramics samples sintered at $1600^{\circ} \mathrm{C}$ for $2 \mathrm{hrs}$ with different ratios of rice husk ash have different peaks, which refer to some of the ceramic phases including corundum $\left(\mathrm{Al}_{2} \mathrm{O}_{3}\right)$ (JCPDS file number 01-0750785), cristobalite $\left(\mathrm{SiO}_{2}\right)$ (JCPDS file number 00-001-0424), mullite $\left(3 \mathrm{Al}_{2} \mathrm{O}_{3} \cdot 2 \mathrm{SiO}_{2}\right)$ (JCPDS file number 00-006-0259), and sillimanite $\left(\mathrm{Al}_{2} \mathrm{SiO}_{5}\right)$ (JCPDS file number 01-088-0890). It was found that, with increasing ratios of rice husk ash and sintering at high temperature, the phases detected in the samples of the porous alumina with rice husk ash included corundum $\left(\mathrm{Al}_{2} \mathrm{O}_{3}\right)$ at $10 \mathrm{wt} \%$ rice husk ash, cristobalite $\left(\mathrm{SiO}_{2}\right)$ 

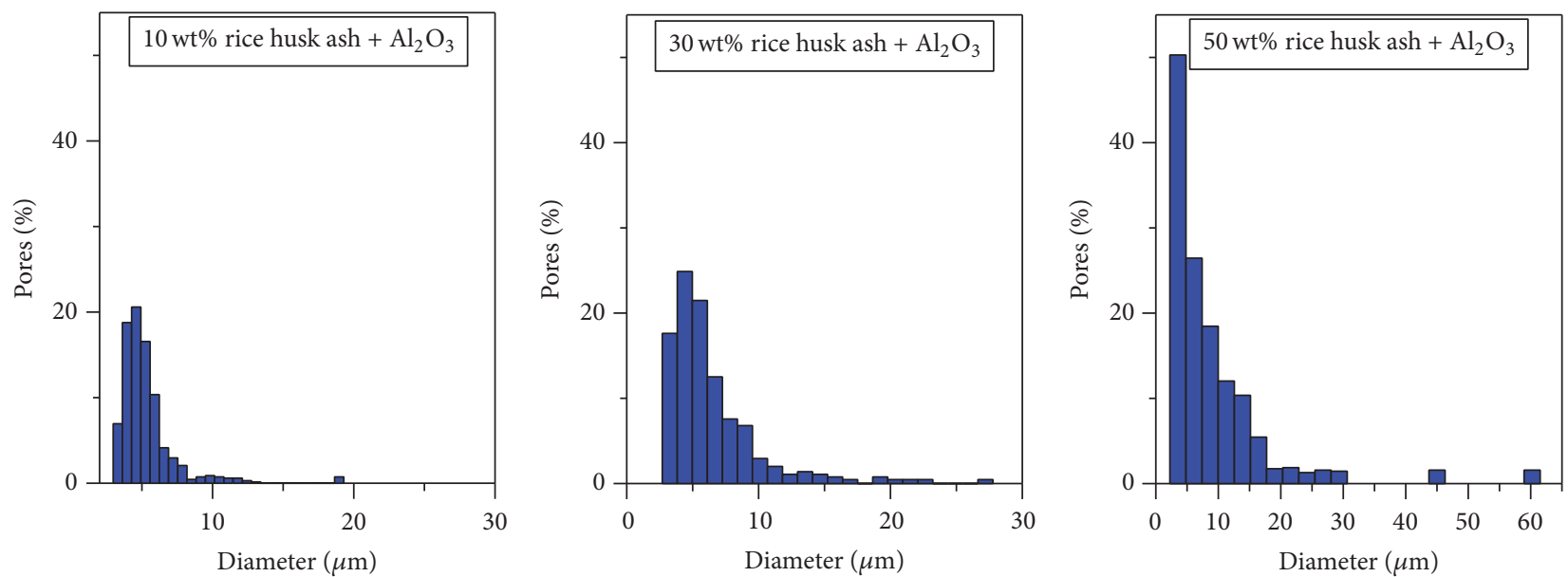

FIGURE 6: Distribution of the open pore size of the samples of porous alumina ceramic sintered at $1600^{\circ} \mathrm{C}$ for 2 hrs with different ratios of rice husk ash.

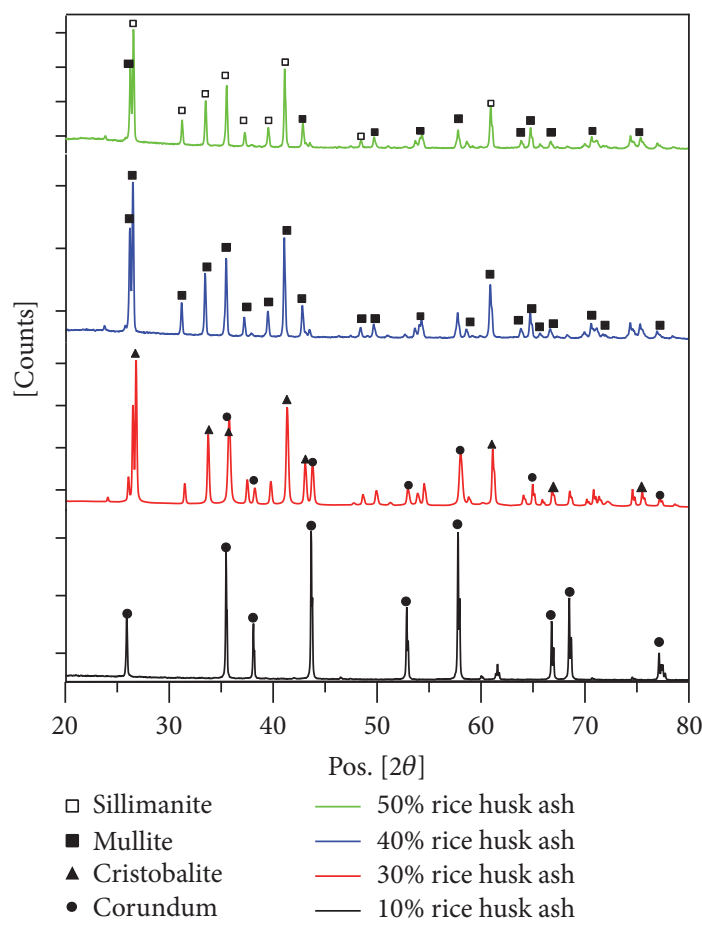

FIGURE 7: XRD pattern for the porous alumina samples sintered at $1600^{\circ} \mathrm{C}$ for $2 \mathrm{hrs}$ with rice husk ash.

and corundum $\left(\mathrm{Al}_{2} \mathrm{O}_{3}\right)$ at $30 \mathrm{wt} \%$ rice husk ash, and mullite $\left(3 \mathrm{Al}_{2} \mathrm{O}_{3} \cdot 2 \mathrm{SiO}_{2}\right)$ at $40 \mathrm{wt} \%$ rice husk ash while sillimanite $\left(\mathrm{Al}_{2} \mathrm{SiO}_{5}\right)$ and mullite $\left(3 \mathrm{Al}_{2} \mathrm{O}_{3} \cdot 2 \mathrm{SiO}_{2}\right)$ existed at $50 \mathrm{wt} \%$ rice husk ash. All these phases were matched with their JCPDS file number.

For the ratio of $10 \mathrm{wt} \%$ rice husk ash, only the corundum $\left(\mathrm{A}_{2} \mathrm{O}_{3}\right)$ phase was detected because the ratio of $\mathrm{SiO}_{2}$ in the rice husk ash was not sufficient to react with $\mathrm{Al}_{2} \mathrm{O}_{3}$ for production or transformation into another ceramic phase like cristobalite $\left(\mathrm{SiO}_{2}\right)$ and mullite $\left(3 \mathrm{Al}_{2} \mathrm{O}_{3} \cdot 2 \mathrm{SiO}_{2}\right)$; this is evident in Figure 7. Based on the XRD pattern, there is no sign of the silica $\left(\mathrm{SiO}_{2}\right)$ peak. Meanwhile, for the ratio of $30 \mathrm{wt} \%$ rice husk ash, the cristobalite $\left(\mathrm{SiO}_{2}\right)$ and corundum $\left(\mathrm{Al}_{2} \mathrm{O}_{3}\right)$ phases were detected, which lead to improvements in the mechanical properties. The big peaks of cristobalite $\left(\mathrm{SiO}_{2}\right)$ can be seen due to the increase in the rice husk ash ratio. After sintering at high temperature, there is no sign of the silica peak for the $40 \mathrm{wt} \%$ rice husk ash sample. This is evident in Figure 7 based on the XRD pattern. This proves that the silica $\left(\mathrm{SiO}_{2}\right)$ reacted with the surrounding alumina $\left(\mathrm{Al}_{2} \mathrm{O}_{3}\right)$ to produce a stable mullite $\left(3 \mathrm{Al}_{2} \mathrm{O}_{3} \cdot 2 \mathrm{SiO}_{2}\right)$ phase, according to the following equation [15]:

$$
3 \mathrm{Al}_{2} \mathrm{O}_{3}+2 \mathrm{SiO}_{2} \longrightarrow 3 \mathrm{Al}_{2} \mathrm{O}_{3} \cdot 2 \mathrm{SiO}_{2}
$$

By increasing the percentage ratio of mullite $\left(3 \mathrm{Al}_{2} \mathrm{O}_{3} \cdot 2 \mathrm{SiO}_{2}\right)$ at $40 \mathrm{wt} \%$, the densification rate was retarded and increased the porosity, which lead to a reduction in the mechanical properties of porous ceramics [42]. The silica peak was also unclear from the $50 \mathrm{wt} \%$ rice husk ash sample. It is believed that the alumina had dissolved into the residual glassy phase of the silica $\left(\mathrm{SiO}_{2}\right)$ to form the mullite $\left(3 \mathrm{Al}_{2} \mathrm{O}_{3} \cdot 2 \mathrm{SiO}_{2}\right)$ and sillimanite $\left(\mathrm{Al}_{2} \mathrm{SiO}_{5}\right)$ or $\left(\mathrm{Al}_{2} \mathrm{O}_{3} \cdot \mathrm{SiO}_{2}\right)$ phases $[43,44]$ according to the following reaction:

$$
\mathrm{Al}_{2} \mathrm{O}_{3}+\mathrm{SiO}_{2} \longrightarrow \mathrm{Al}_{2} \mathrm{O}_{3} \cdot \mathrm{SiO}_{2}
$$

Thus, it can be concluded that all these phases of the ceramics formed have an effect on the mechanical properties of porous ceramics [15]. In this case, the ratios of the rice husk ash controlled the sintering parameters such as the density, the average pore size, porosity, and the formation of the phases.

Figure 8 illustrates the FESEM images of the samples of porous alumina ceramic with different ratios of rice husk ash $(10 \mathrm{wt} \%, 30 \mathrm{wt} \%$, and $50 \mathrm{wt} \%$ rice husk ash; the sintering temperature was set at $1600^{\circ} \mathrm{C}$ for $2 \mathrm{hrs}$ ). An increase in the ratio of the rice husk ash not only causes an increase in the porosity but also brings changes to the microstructure. Figures $8(\mathrm{a}), 8(\mathrm{~b})$, and $8(\mathrm{c})$ show the longitudinal shape of the pores in the samples of the porous alumina ceramics, which were attributed to the shape and size of the pore agent 


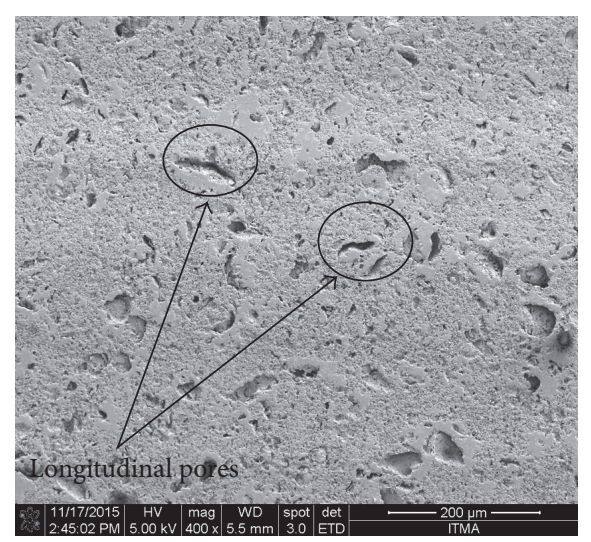

(a)

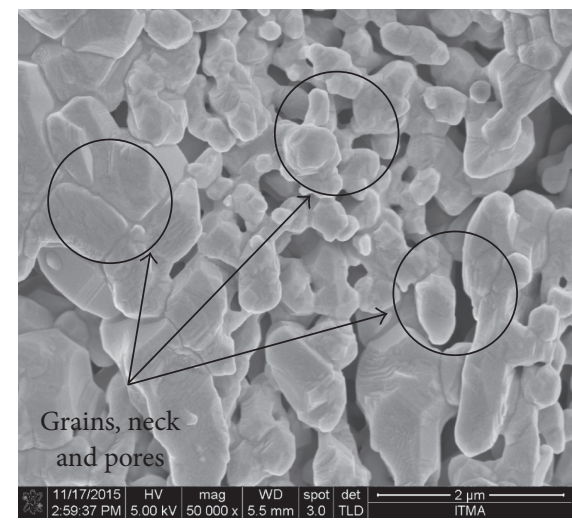

(d)

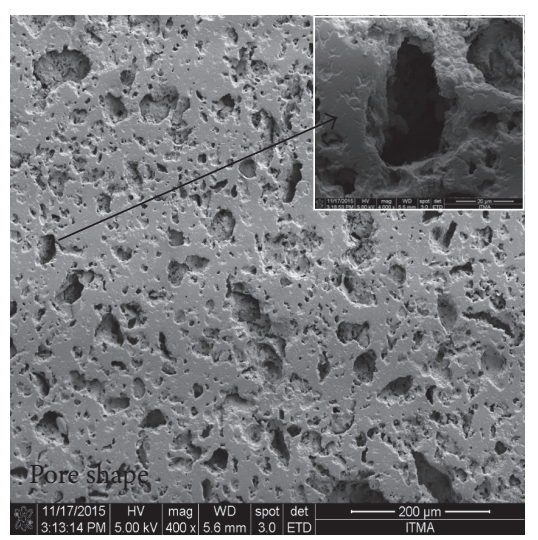

(b)

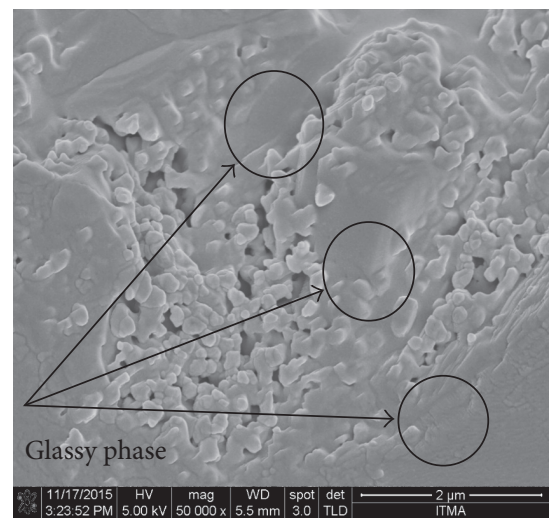

(e)

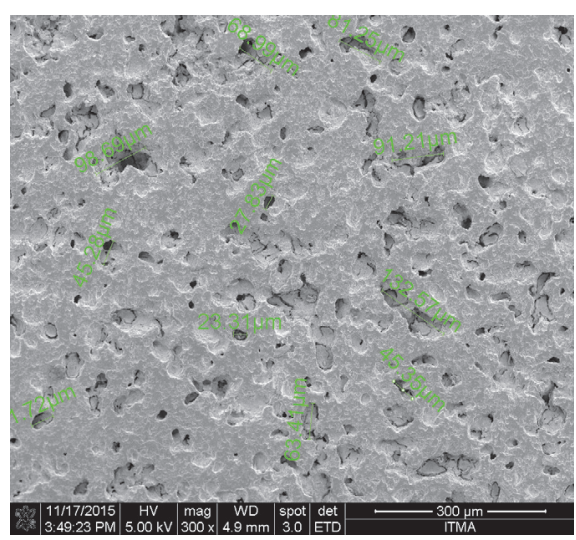

(c)

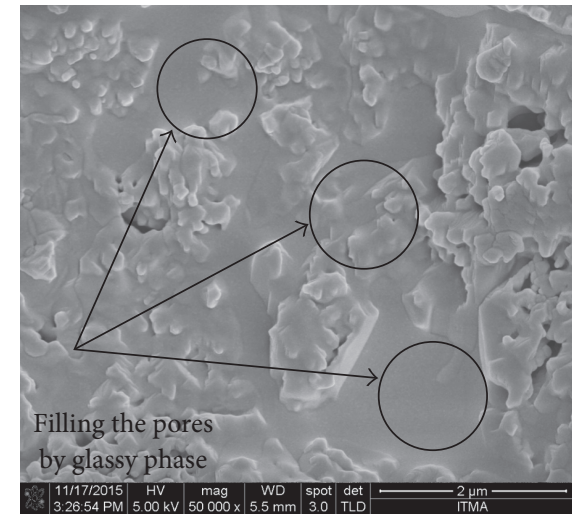

(f)

FIGURE 8: FESEM images of the samples of porous ceramic sintered at $1600^{\circ} \mathrm{C}$ for $2 \mathrm{hrs}$ with different ratios of rice husk ash; (a, d) $10 \mathrm{wt} \%$ rice husk ash, (b, e) $30 \mathrm{wt} \%$ rice husk ash, and (c, f) $50 \mathrm{wt} \%$ rice husk ash.

particles as shown in Figure 2. The pores, grains, glassy phase, and neck shapes of the samples of the porous alumina can be clearly seen in Figures 8(d), 8(e), and 8(f). The growth of the grains and necks was a result of sintering at high temperature [45], while each gap between the particles and the neck becomes a pore in addition to the effects of the pore agent [46]. In addition, the different sizes of the pores resulted in an increase in the ratio of the rice husk ash and sucrose burnout [15]. The linking of the open pores resulted in fine and big pores.

Figures $8(\mathrm{e})$ and $8(\mathrm{f})$ present the glassy phase of $30 \mathrm{wt} \%$ and $50 \mathrm{wt} \%$ rice husk ash during sintering at $1600^{\circ} \mathrm{C}$ for $2 \mathrm{hrs}$. The presence of the glassy phase for $30 \mathrm{wt} \%$ and $50 \mathrm{wt} \%$ rice husk ash was to fill the porous structure, which leads to a decrease in the porosity from $48.09 \%$ to $47.64 \%$ and from $49.45 \%$ to $49.04 \%$ for $30 \mathrm{wt} \%$ and $50 \mathrm{wt} \%$ rice husk ash, respectively [31]. Hence, decreasing the porosity, through the formations of the glassy phase ceramic phases, has improved the mechanical properties.

\section{Conclusion}

The use of alumina and commercial rice husk ash as a source of silica $\left(\mathrm{SiO}_{2}\right)$ and as a pore agent has successfully resulted in the preparation of porous mullite and cristobalite-corundum ceramic composite materials. The porosity increased with an increase in the ratios of the rice husk ash from $10 \mathrm{wt} \%$ to $50 \mathrm{wt} \%$. However, the tensile and compressive strengths showed an initial decrease, followed by an increase. The the improvement in the mechanical properties was attributed to the formation of the phases of the ceramic (sillimanite, mullite, corundum, and cristobalite) at high sintering temperature and higher rice husk ash ratios. Finally, the distributions of the pore size corresponded to the ratio of the rice husk ash.

\section{Competing Interests}

The authors declare that they have no competing interests.

\section{Acknowledgments}

The financial support provided by Putra Grant 2013 (GPIBT/ 2013/9410600) is much appreciated. The authors would like to thank and appreciate the Iraqi Government/Ministry of Higher Education and Scientific Research for its financial support. 


\section{References}

[1] K. Hua, A. Shui, L. Xu, K. Zhao, Q. Zhou, and X. Xi, "Fabrication and characterization of anorthite-mullite-corundum porous ceramics from construction waste," Ceramics International, vol. 42, no. 5, pp. 6080-6087, 2016.

[2] G. Xu, Y. Ma, H. Cui, G. Ruan, Z. Zhang, and H. Zhao, "Preparation of porous mullite-corundum ceramics with controlled pore size using bioactive yeast as pore-forming agent," Materials Letters, vol. 116, pp. 349-352, 2014.

[3] F. Nyongesa, N. Rahbar, S. Obwoya, J. Zimba, B. O. Aduda, and W. Soboyejo, "An investigation of thermal shock in porous clay ceramics," ISRN Mechanical Engineering, vol. 2011, Article ID 816853, 9 pages, 2011.

[4] E. S. Gómez, J. D. J. A. F. Cuautle, and O. T. Jiménez, "Preparation and sintering effect in quartz-barium titanate porous ceramics and permeability modulation using an implanted electrode," Advances in Materials Science and Engineering, vol. 2014, Article ID 721245, 5 pages, 2014.

[5] A. Tomba, M. A. Camerucci, G. Urretavizcaya, A. L. Cavalieri, M. A. Sainz, and A. Caballero, "Elongated mullite crystals obtained from high temperature transformation of sillimanite," Ceramics International, vol. 25, no. 3, pp. 245-252, 1999.

[6] H. S. Tripathi, B. Mukherjee, S. K. Das, A. Ghosh, and G. Banerjee, "Effect of sillimanite beach sand composition on mullitization and properties of $\mathrm{Al}_{2} \mathrm{O}_{3}-\mathrm{SiO}_{2}$ system," Bulletin of Materials Science, vol. 26, no. 2, pp. 217-220, 2003.

[7] Y. M. Park, T. Y. Yang, S. Y. Yoon, R. Stevens, and H. C. Park, "Mullite whiskers derived from coal fly ash," Materials Science and Engineering A, vol. 454-455, pp. 518-522, 2007.

[8] M. Serra, M. Conconi, M. Gauna, G. Suárez, E. Aglietti, and N. Rendtorff, "Mullite $\left(3 \mathrm{Al}_{2} \mathrm{O}_{3} \cdot 2 \mathrm{SiO}_{2}\right)$ ceramics obtained by reaction sintering of rice husk ash and alumina, phase evolution, sintering and microstructure," Journal of Asian Ceramic Societies, vol. 4, no. 1, pp. 61-67, 2016.

[9] J.-M. Wu, X.-Y. Zhang, J. Xu et al., "Preparation of porous $\mathrm{Si}_{3} \mathrm{~N}_{4}$ ceramics via tailoring solid loading of $\mathrm{Si}_{3} \mathrm{~N}_{4}$ slurry and $\mathrm{Si}_{3} \mathrm{~N}_{4}$ poly-hollow microsphere content," Journal of Advanced Ceramics, vol. 4, pp. 260-266, 2015.

[10] K. Sengphet, K. Pasomsouk, T. Sato, M. A. Fauzi, O. Radzali, and S. P. Pinang, "Fabrication of porous clay ceramics using kenaf powder waste," International Journal of Scientific and Research Publications, vol. 3, no. 8, 2013.

[11] D. E. Njeumen Nkayem, J. A. Mbey, B. B. Kenne Diffo, and D. Njopwouo, "Preliminary study on the use of corn cob as pore forming agent in lightweight clay bricks: physical and mechanical features," Journal of Building Engineering, vol. 5, pp. 254-259, 2016.

[12] P. Sooksaen, S. Suttiruengwong, K. Oniem, K. Ngamlamiad, and J. Atireklapwarodom, "Fabrication of porous bioactive GlassCeramics via decomposition of natural fibres," Journal of Metals, Materials and Minerals, vol. 18, pp. 85-91, 2008.

[13] Y. Dong, J.-E. Zhou, B. Lin et al., "Reaction-sintered porous mineral-based mullite ceramic membrane supports made from recycled materials," Journal of Hazardous Materials, vol. 172, no. 1, pp. 180-186, 2009.

[14] J. Cao, X. Dong, L. Li, Y. Dong, and S. Hampshire, "Recycling of waste fly ash for production of porous mullite ceramic membrane supports with increased porosity," Journal of the European Ceramic Society, vol. 34, no. 13, pp. 3181-3194, 2014.

[15] K. Mohanta, A. Kumar, O. Parkash, and D. Kumar, "Processing and properties of low cost macroporous alumina ceramics with tailored porosity and pore size fabricated using rice husk and sucrose," Journal of the European Ceramic Society, vol. 34, no. 10, pp. 2401-2412, 2014.

[16] G. L. Re, F. Lopresti, G. Petrucci, and R. Scaffaro, "A facile method to determine pore size distribution in porous scaffold by using image processing," Micron, vol. 76, pp. 37-45, 2015.

[17] M. Gan and J. Wang, Applications of Image Processing Technique in Porous Material Characterization, InTech Open Access, 2012.

[18] S. R. Elsen and T. Ramesh, "Optimization to develop multiple response hardness and compressive strength of zirconia reinforced alumina by using RSM and GRA," International Journal of Refractory Metals and Hard Materials, vol. 52, pp. 159-164, 2015.

[19] W. C. Oliver and G. M. Pharr, "Measurement of hardness and elastic modulus by instrumented indentation: advances in understanding and refinements to methodology," Journal of Materials Research, vol. 19, no. 1, pp. 3-20, 2004.

[20] A. s. ASTM standard C 1327-03, "ASTM standard C 1327-03 Standard Test Method for Vickers Indentation Hardness of Advanced Ceramics," 2004.

[21] B. S. M. Seeber, U. T. Gonzenbach, and L. J. Gauckler, "Mechanical properties of highly porous alumina foams," Journal of Materials Research, vol. 28, no. 17, pp. 2281-2287, 2013.

[22] J. A. Junkes, B. Dermeik, B. Gutbroda, D. Hotzab, P. Greila, and N. Travitzky, "Influence of coatings on microstructure and mechanical properties of preceramic paper-derived porous alumina substrates," Journal of Materials Processing Technology, vol. 213, no. 2, pp. 308-313, 2013.

[23] L. Hu, R. Benitez, S. Basu, I. Karaman, and M. Radovic, "Processing and characterization of porous $\mathrm{Ti}_{2} \mathrm{AlC}$ with controlled porosity and pore size," Acta Materialia, vol. 60, no. 18, pp. 6266-6277, 2012.

[24] R. L. Menchavez and L.-A. S. Intong, "Red clay-based porous ceramic with pores created by yeast-based foaming technique," Journal of Materials Science, vol. 45, no. 23, pp. 6511-6520, 2010.

[25] L. F. Hu and C.-A. Wang, "Effect of sintering temperature on compressive strength of porous yttria-stabilized zirconia ceramics," Ceramics International, vol. 36, no. 5, pp. 1697-1701, 2010.

[26] J. Dittmann and N. Willenbacher, "Micro structural investigations and mechanical properties of macro porous ceramic materials from capillary suspensions," Journal of the American Ceramic Society, vol. 97, no. 12, pp. 3787-3792, 2014.

[27] J.-H. Eom, Y.-W. Kim, and S. Raju, "Processing and properties of macroporous silicon carbide ceramics: a review," Journal of Asian Ceramic Societies, vol. 1, no. 3, pp. 220-242, 2013.

[28] O. L. Ighodaro, O. I. Okoli, M. Zhang, and B. Wang, "Ceramic preforms with 2D regular channels for fabrication of metal/ceramic-reinforced composites," International Journal of Applied Ceramic Technology, vol. 9, no. 2, pp. 421-430, 2012.

[29] G. Görhan and O. Şimşek, "Porous clay bricks manufactured with rice husks," Construction and Building Materials, vol. 40, pp. 390-396, 2013.

[30] K. A. Matori, M. Haslinawati, Z. Wahab, H. Sidek, T. Ban, and W. Ghani, "Producing amorphous white silica from rice husk," MASAUM Journal of Basic and Applied Sciences, vol. 1, no. 3, pp. 512-515, 2009.

[31] K. Hua, A. Shui, L. Xu, K. Zhao, Q. Zhou, and X. Xi, "Fabrication and characterization of anorthite-mullite-corundum porous ceramics from construction waste," Ceramics International, vol. 42, no. 5, pp. 6080-6087, 2016. 
[32] W. Guo, H. Lu, and C. Feng, "Influence of $\mathrm{La}_{2} \mathrm{O}_{3}$ on preparation and performance of porous cordierite from rice husk," Journal of Rare Earths, vol. 28, no. 4, pp. 614-617, 2010.

[33] Z. Negahdari, M. Willert-Porada, and C. Pfeiffer, "Mechanical properties of dense to porous alumina/lanthanum hexaaluminate composite ceramics," Materials Science and Engineering A, vol. 527, no. 12, pp. 3005-3009, 2010.

[34] G. P. Kennedy, K.-Y. Lim, Y.-W. Kim, I.-H. Song, and H.-D. Kim, "Effect of SiC particle size on flexural strength of porous selfbonded SiC ceramics," Metals and Materials International, vol. 17, no. 4, pp. 599-605, 2011.

[35] D.-M. Liu, "Influence of porosity and pore size on the compressive strength of porous hydroxyapatite ceramic," Ceramics International, vol. 23, no. 2, pp. 135-139, 1997.

[36] L. Yin, X. Zhou, J. Yu, and H. Wang, "Preparation of high porous silicon nitride foams with ultra-thin walls and excellent mechanical performance for heat exchanger application by using a protein foaming method," Ceramics International, vol. 42, no. 1, pp. 1713-1719, 2016.

[37] N. Kayal, A. Dey, and O. Chakrabarti, "Synthesis of mullite bonded porous $\mathrm{SiC}$ ceramics by a liquid precursor infiltration method: effect of sintering temperature on material and mechanical properties," Materials Science and Engineering A, vol. 556, pp. 789-795, 2012.

[38] W. Yan, N. Li, and B. Han, "Effects of sintering temperature on pore characterisation and strength of porous corundum-mullite ceramics," Journal of Ceramic Processing Research, vol. 11, no. 3, pp. 388-391, 2010.

[39] B. V. Manoj Kumar, J.-H. Eom, Y.-W. Kim, I.-H. Song, and H.D. Kim, "Effect of aluminum hydroxide content on porosity and strength of porous mullite-bonded silicon carbide ceramics," Journal of the Ceramic Society of Japan, vol. 119, no. 1389, pp. 367-370, 2011.

[40] P. Lemes-Rachadel, H. Birol, A. P. N. Oliveira, and D. Hotza, "Development of alternative glass ceramic seal for a planar solid oxide fuel cell," Advances in Materials Science and Engineering, vol. 2012, Article ID 346280, 6 pages, 2012.

[41] J. Cao, J. Lu, L. Jiang, and Z. Wang, "Sinterability, microstructure and compressive strength of porous glass-ceramics from metallurgical silicon slag and waste glass," Ceramics International, vol. 42, no. 8, pp. 10079-10084, 2016.

[42] A. Sedaghat, E. Taheri-Nassaj, G. D. Soraru, and T. Ebadzadeh, "Microstructure development and phase evolution of aluminamullite nanocomposite," Science of Sintering, vol. 45, no. 3, pp. 293-303, 2013.

[43] L. Zhu, Y. Dong, S. Hampshire, S. Cerneaux, and L. Winnubst, "Waste-to-resource preparation of a porous ceramic membrane support featuring elongated mullite whiskers with enhanced porosity and permeance," Journal of the European Ceramic Society, vol. 35, no. 2, pp. 711-721, 2015.

[44] R. C. Bradt, "The sillimanite minerals: andalusite, kyanite, and sillimanite," in Ceramic and Glass Materials, pp. 41-48, Springer, Berlin, Germany, 2008.

[45] S. Ding, S. Zhu, Y.-P. Zeng, and D. Jiang, "Fabrication of mullitebonded porous silicon carbide ceramics by in situ reaction bonding," Journal of the European Ceramic Society, vol. 27, no. 4, pp. 2095-2102, 2007.

[46] W. D. Callister Jr. and D. G. Rethwisch, Materials Science and Engineering, chapter 12, John Wiley \& Sons, Inc, New York, NY, USA, 8th edition, 2010. 

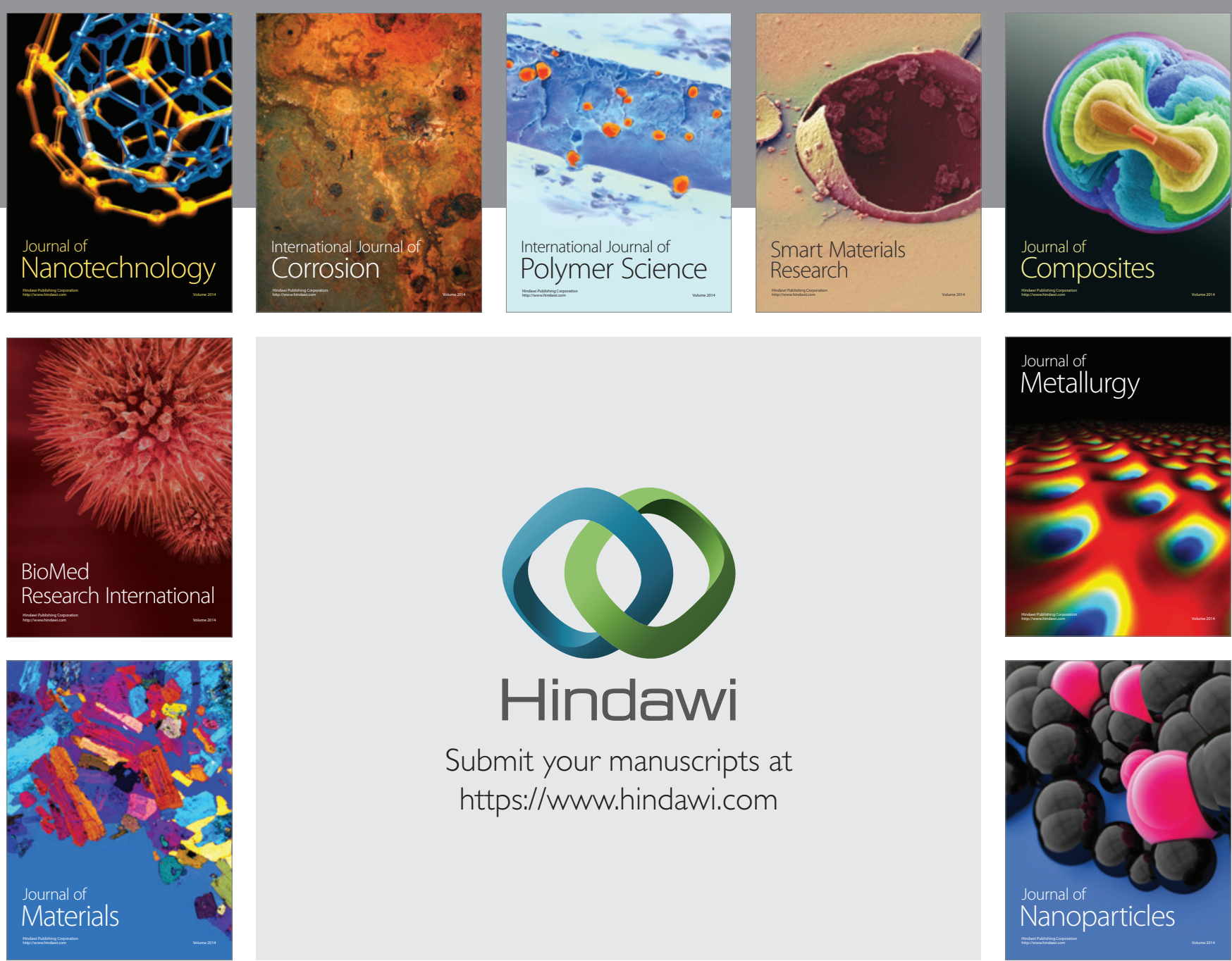

\section{Hindawi}

Submit your manuscripts at

https://www.hindawi.com

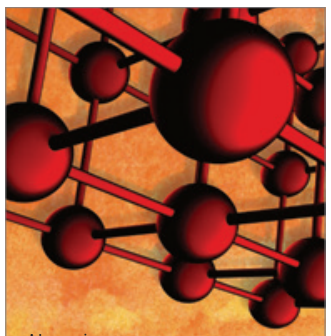

Materials Science and Engineering
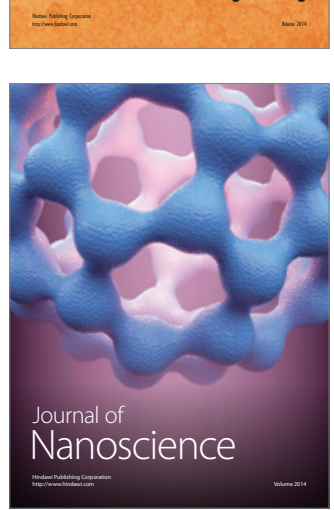
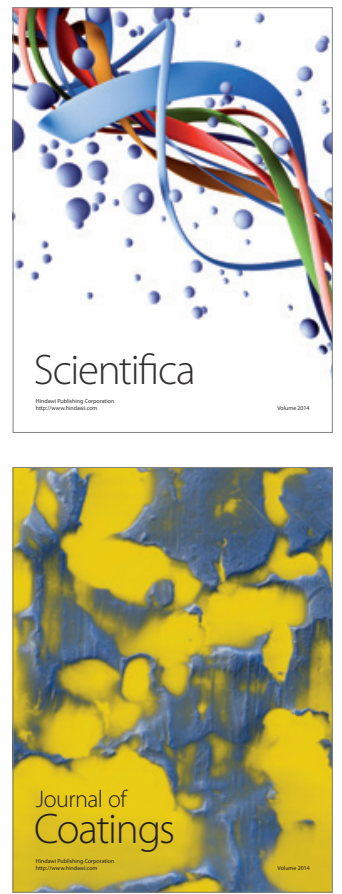
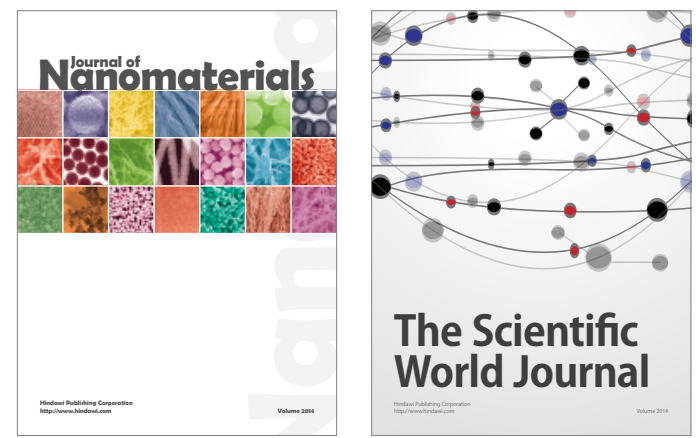

The Scientific World Journal
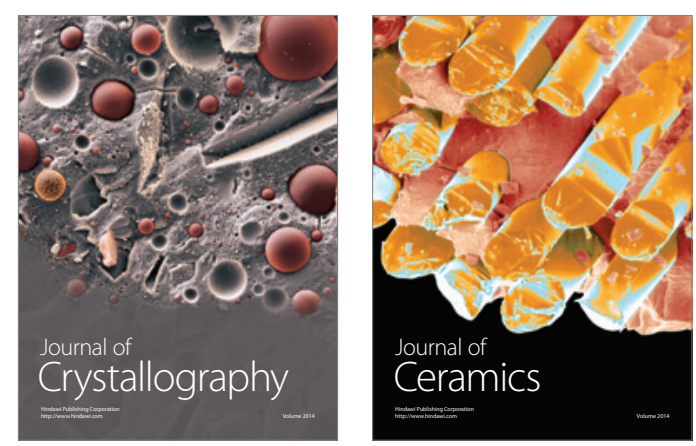
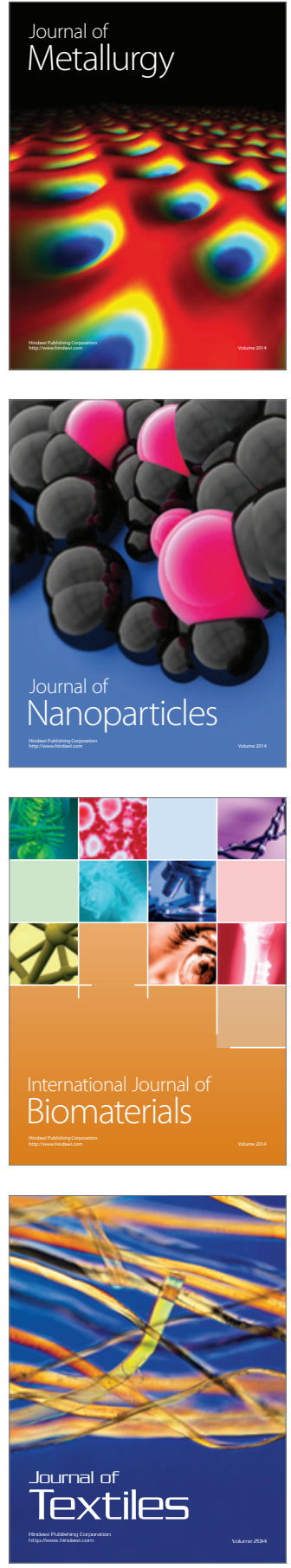